\title{
Role of Micro-Influencers in Affecting Behavioural Intentions
}

\author{
Shiromani Gupta, Rachna Mahajan
}

\begin{abstract}
Purpose - Micro-influencers are often positioned between common social media users and celebrities. Using them for endorsements is a current and prospective aspect of social media marketing. This paper studies the credibility of microinfluencers and their impact on behavioral intentions of their followers.

Designing - This paper take benefit of the qualitative analysis on responses received from 135 Instagram users who follow at least one micro-influencer and have purchased at least one product promoted by them. Responses from 15 microinfluencers and 08 small business owners (who have roped in regional micro-influencers) have also been studied.

Findings - The paper identifies that micro-influencers are gaining much popularity in India, since the users find them relatable and trustworthy. The attractive advertisements (in form of posts \& stories) leave an impact on followers and also shape their purchase and viral intentions.

Research limitations/implications- The methodology adopted for this paper is of qualitative nature and the responses collected from various sources were verified against the available literature. Same could be done in qualitative terms.

Practical implications - The use of micro-influencers for social media marketing is on the rise. Studying their impact especially for small businesses that can't spend on other cost intensive advertising alternatives becomes relevant.

Originality/value -This research contributes to studying microinfluencer role in affecting the behavioral intentions of social media users in India. Not many studies have been conducted in this regard and even less considering Instagram as a platform
\end{abstract}

Keywords - Marketing, Social media marketing, Influencer Marketing, Instagram, India.

\section{INTRODUCTION}

A financial analyst left her job after becoming a fashion and beauty influencer. This happened when her Instagram account became popular and clothing brands started to approach for collaborations. This is not a story of one but a lot of other common social media users. They found that their opinions mattered more than others.

Micro-influencers are social media users who are famous and appreciated by their followers. They aren't celebrities in real sense but can be termed as micro-celebrities.

Revised Manuscript Received on December 5, 2019.

* Correspondence Author

Shiromani Gupta, Ph. D. Research Scholar, The Business School, University of Jammu, Jammu (J\&K), INDIA

Dr. Rachna Mahajan, Sr. Assistant Prof., The Business School, University of Jammu, Jammu (J\&K), INDIA
Users who become micro-influencers differ from traditional celebrities is that sense that former become famous by content creation on social platforms where as the traditional celebrities are famous even before joining social media (Chae, 2017; Djafarova \& Rushworth, 2017; Khamis et al., 2016). Another difference is based on their relationship with their followers. The micro-celebrities forma bidirectional relation, which offers an insight into their private lives whereas traditional celebrities interact with huge fan base but form rare personal link. These relationship characteristics indicate clear distinction between the two (Chae, 2017; Djafarova \& Rushworth, 2017; Khamiset al., 2016).

\subsection{Influencer}

Influencer is a person, who at relevant market place, has a reach greater than average or impact through word of mouth ("RESEARCH SHOWS MICRO-INFLUENCERS", 2016). Influencer is quite a broad term. They can differ in terms of their power of influence, their reach and their engagement with audience. Influencers can be grouped into three categories: Mega-influencers, Macro-influencers \& Microinfluencers. Micro-Influencers are common people with following around $10 \mathrm{~K}$ or less but having a strong relationship with followers (Neil, 2018; "THE DIFFERENCE", 2016; Revell, 2017). On the contrary, other authors like Weinswig (2016) \& Sammis (2017) find these counts to be vague. The spectrum of micro-influencer can't be defined by any arbitrary follower count as these thresholds are completely subjective (Sammis, 2017). More than the follower count, their ability to actually influence through authenticity and curation matters (Weinswig, 2016). Since, there is no well accepted definition or categorization of micro-influencers, the study shall consider microinfluencers to be the ones who aren't traditional celebrities and those having huge followers on social media due to their content sharing skills, engagement rate \& a bidirectional relationship with their audience.

\subsection{Social Media Platform - Instagram}

Instagram, a social networking platform, which allows sharing visual content, is found to be the most robust platform for following influencers (Djafarova and Rushworth, 2017). It's visual content and appealing look helps the followers to get a glimpse of other's lifestyle and physical appearance that they consider ideal. A number of brands consider influencer marketing on Instagram to be a part of their digital advertising strategy. Instagram is multiple times higher than Facebook, multiple times higher than Pinterest and multiple times higher that of Twitter. Influences on various sorts of online networking are known with the names tending to the stage, for example, Instagram (YouTube , Twitter Web based life isn't only being utilized

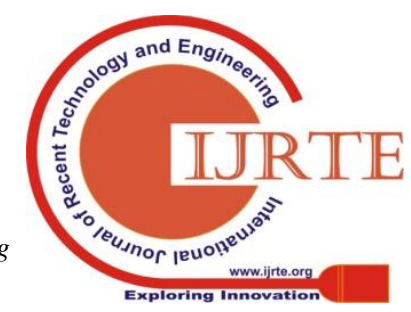


interpersonal interaction and substance sharing, yet additionally as a stage for monetary interests of organizations

\subsection{Micro Influencer Credibility \& Related Followers' Behavioural Intentions}

Micro-influencers are known to paint their instagram accounts to a desired lifestyle and create an ideal image in their category of expertise, which other users find to be attractive and trustworthy. As per Eagar and Dann (2016), numerous clients who are celebrated on Instagram, positioning themselves between a big name and a regular individual to extend themselves as dependable sources to their supporters. The social influence through their posts showing the way of powerful or the greatest an item or administration is and consequently attempt to vary the reasoning of the other web based life clients .Based on the writing accessible for big name and the associated supporting, miniaturized scale influencers could estimated building .

Brand mentality is seen as the most significant indicating of client conducting goals towards administration by advertisers. Thinking about its impact, in perspective on content small scale impacts post via web-based networking media will be a goal of the present examination. Miniaturized scale influencer's ubiquity, association to their adherents and mastery in their field put them on the rundown of building an effect on Behavioral aims of web based life clients. A few examinations have expressed the mentality towards promotion and branding to positively affect buyers' buy aims of the publicized item and likewise on viral goals . Viral expectations of an online networking incorporating preferring, remarking, sharing a post, following brands and additionally tell others it.

\section{RESEARCH METHODOLOGY}

This paper uses qualitative analysis on feedback received from 135 instagram users who follow at least one microinfluencer and have purchased at least one product promoted by them. Responses from 15 micro-influencers and 08 small business owners who have roped in regional microinfluencers for promotion for their product/brand in categories of Fashion, Beauty and Fitness have also been studied.

The choice of a single visual social media platforms, Instagram is made since it has been the most important influencer marketing channel in 2018 followed by Facebook \& Twitter ("Infographic", 2019).It has also been ranked as strategically most important Social Media channel for Influencer Marketing, Youtube being the second one on the list ("Influencer Marketing Survey", 2019). Instagram has divided accounts into 12 categories namely Books \& Magazines, Brands \& Products, Companies \& Organizations, Event Sources, Films, Local Businesses, Music, People, Sports, Television, Website \& Bloggers \& Other. These categories have a total 277 sub-categories. Out of these sub-categories, ten industry verticals (Photography, Art \& Design, Travel, Business, Fitness, Food \& Drink, Fashion, Entertainment, Beauty and Home \& Lifestyle) have been formed ("Instagram Influencer Rates", 2018). These verticals were formed by segmenting influencers on the category they mentioned as their primary focus.

For the present study, an experiment was conducted among 150 Instagram users wherein the users were asked to group the 10 industry verticals on basis of similarity of posts, keeping a maximum of 3 categories in one group without repetition. The most common group hence formed was Fashion, Beauty and Fitness.

In the first round, center gathering interviews were led with a gathering size of 8-10 individuals. The inquiries presented to each gathering of Instagram clients were on the idea of validity parameters of the smaller scale influencers they follow, the effect these influencers have on their buy and viral expectations. Respondents were guided to distinguish and classifications the related segments of validity of miniaturized scale influencers. Follow-up questions were on the buy conduct and the goal to like, offer and remark on the substance posted by small scale influencers. Comparable center gathering interviews were directed with 15 miniaturized scale influencers in 2 gatherings to acquire an assorted variety of input sources. A last round of central gathering meeting was directed with 08 entrepreneurs for getting their view on come back from putting resources into smaller scale impacts for advancements and the variables for picking a specific miniaturized scale impacts. The term of each center gathering conversation was half hour. The reactions acquired from each of the three gatherings were recorded and broke down in the light of existing writing accessible. All the key terms proposed by respondents have been classified under different existing segments of impacts believable. Essentially, reactions on the social and indispensable goals have been dissected.

\section{EMERGED CREDIBILITY DIMENSIONS}

As a result of content analysis, a total of 22 unique terms/factors influencing micro-influencer's credibility emerged from the discussions with the users and microinfluencers. The components include Expert, Specialist, Proficient, Knowledgeable, Skilled, Professional, Experienced, Trustworthy, Dependable, Ethical, Honest, Positive, Committed, Emphatic, Elegant, Assertive, Vigorous, Attractive, Charming, Delightful, Charismatic and Classy. On grouping these factors dimensions similar to Ohanian (1990) scale developed. Three constructs to measure the effectiveness specifically in advertisement course were given, these are, perceived expertise, trustworthiness and attractiveness.

Another view on credibility was related to the number of followers micro-influencers should have to be recognised as a credible one. The focus groups could not decide a number range to the same. A few others came up with a viewpoint of not just considering the follower count of a microinfluencer but also the number of accounts they are following. So, the higher the value of ratio more credible a micro-influencer is. This aspect of considering followers to following ratio to measure credibility was mostly agreed upon but wasn't too strong as not much empirical evidence support the same.

Source credibility is used in analyzing the effectiveness of an endossement. A credible endorser is generally perceived positively by consumers

Various dimensions defining credibility have been researched by source credibility scholars (Berlo et al., 1969;

Hovland et al., 1953; McCroskey, 1966; Wynn, 1987). Influencer's 
perceived credibility explains the effectiveness of a message to be dependent on perceived level of expertise and trustworthiness of an influencer (Hovland et al., 1953; Hovland and Weiss, 1951; Ohanian, 1990). Perceived expertness and trustworthiness are considered to be the two components of credibility by Hovland et al. (1953, p. 21). In some studies, attractiveness has also been considered as an important dimension of credibility (Ohanian, 1990; Goldsmith et al., 2000). The need for more consistency in source credibility was addressed by Ohanian (1990) by developing a fifteen-point tri-component scale to rank celebrity endorsers using, expertise and trustworthiness dimensions from Hovland et al. (1953) and the attractiveness dimension from McGuire (1985).

Literature supports the use of both type of endorsers, celebrities as well as peers. Celebrities score well on expertise (Ohanian, 1991; O’Mahony \& Meenaghan, 1997) and while peers are considered to be more trustworthy and similar to consumers (Munnukka et al., 2016; Willemsen et al., 2012). Since, micro-influencers possess traits of both; they have the potential to be quite influential to Consumer Behavior. Consumer perceived credibility of a social media influencer has been linked positively to purchase intentions (Schapers, 2018).

\section{IMPACT OF MICRO-INFLUENCERS CREDIBILITY ON BEHAVIOURAL INTENTIONS}

The content analysis of consumer and micro-influencers focus group discussion was done. It leads to credibility dimensions creating most impact on follower's perception of content posted by the micro-influencers. The content is posted in form of posts or as stories. The perception of content leads to formation of intentions of followers. This was mainly on their purchase intention and viral intention. Purchase intention was agreed upon being the final step a follower could take. This is often preceded by the Viral intention which is not just liking or commenting on the micro-influencer post but also sharing the posts or further the product/ brand being promoted.

Some studies relate perceived credibility and purchase intention,Perceived credibility of an influencer on Instagram and their purchase intention are correlated positively (Sertoglu, Catli \& Korkmaz, 2014; Rebelo, 2017).There have been many studies which relate source credibility and purchase intention but none has been conducted specifically on Instagram micro-influencers with relation to their impact on Indian users . Hence, the current study exposes the affect perceived credibility of micro-influences has on the purchase intentions of said Instagram users.

According to Mahapatra \& Mishra (2017), acceptance of e-word-of-mouth depends upon source credibility and tie strength. Acceptance of e-word-of-mouth plays a mediating role that confirms that people forward information online only if they accept it (Mahapatra, 2017). Since, viral intention not only includes liking, commenting or sharing a post but also the intention of a user to follow brands and to recommend it to others (Messiaen 2017), it can be seen that source credibility is linked to viral intention of the users (Gunawan 2015). Atwal, H \& Sandhu, V. (2019) developed and analyzed conceptual model related to Employee Engagement in organizations. Though, not much literature is available on this relationship and none with respect to micro-influencers credibility and viral intentions of customers towards their Instagram posts, the present research tried to study the same.

\section{INVESTMENT AND RETURNS WITH MICRO-INFLUENCERS}

Content produced from center gathering conversation of 08 entrepreneurs was broke down. Various methods for advancements through smaller scale influencers as examined by the gathering were Sharing Tips, How To's, Announcements, Product Reviews, Account Takeovers, Giveaways, Content Partnerships, Paid associations, and so forth. Costs identified with roping in small scale influencers were summarized as: Payment in real money, Product giveaway, Amount of time contributed, Commissions to different gatherings included, Expertise to build the arrangements, and so forth. . Then again the center gathering thought of the normal advantages which could be acknowledged, for example, Increased deals henceforth Revenue created, better commitment rates, additionally following on the brand's record, more prominent client produced content, brand relatedness and feelings, and so forth. Most individuals in the gathering settled upon item part with as the cost in question and expanded deals, more noteworthy brand mindfulness and client produced content as the profits.

A couple of studies propose some comparative parts of ROI with the smaller scale influencers. For brands to draw in with shoppers on social stages, utilizing small scale influencers would drive imperceptibility and commitment. At last it decidedly influences brand dedication and deals, with a small scale spending plan. The investigations support, bigger the accompanying of an influencer, lower is the commitment rate. Thus, a shrewd and ideal mix of miniaturized scale influencers and superstars raises ROI of a crusade (Wissman, 2018).

Thus, It is critical to take note of that Return On Investment is higher with littler influencers. Likewise it is a significant practical alternative for brands and business with little venture spending plan for advancements. The commitment rate with the small scale influencers is much higher and consequently prompts better brand relatedness and more noteworthy deals.

\section{CONCLUSION}

This paper brings into light the rising significance of smaller scale influencers in online networking promoting. Impact's validity being the checking factor and conduct expectations being the final products. It is inferred that the ROI on smaller scale influencers is at peak and it is a decent alternative for advancement via web-based networking media in any event, for private ventures. Different elements which influence the small influencers believably have likewise been determined and checked with the accessible writing.

Published By:

Blue Eyes Intelligence Engineering

191 \& Sciences Publication 
Thus, it tends to be said that interest in miniaturized scale impacts is a speculation of advantage and great returns and this choice is being investigated in many creating nations including India

\section{REFERENCES}

1. Abidin, C. (2016). “Aren't These Just Young, Rich Women Doing Vain Things Online?": Influencer Selfies as Subversive Frivolity. Social

2. Berlo, D. K., Lemert, J. B., \& Mertz, R. J. (1969). Dimensions for Evaluating the Acceptability of Message Sources. Public Opinion Quarterly, 33(4), 563-576.

3. Biehal, G., Stephens, D., \& Curio, E. (1992). Attitude toward the Ad and Brand Choice. Journal of Advertising, 21(3), 19-36.

4. Chae, J. (2017). Virtual makeover: Selfie-taking and social media use increase selfie-editing frequency through social comparison.

5. Countries with most Instagram users 2019 | Statista. (2019). Retrieved October 12, 2019

6. Djafarova, E., \& Rushworth, C. (2017). Exploring the credibility of online celebrities Instagram profiles in influencing the purchase decisions of young female users.

7. Eagar, T., \& Dann, S. (2016). Classifying the narrated \#selfie: genre typing human-branding activity. European Journal of Marketing, 50(9/10), 1835-185.

8. 8Garifova, L. F. (2016). Realization of small businesses economic interests on instagram. Journal of Economics and Economic Education Research

9. Guido, G., Peluso, A. M., \& Moffa, V. (2011). Beardedness in advertising: Effects on endorsers credibility and purchase intention. Journal of Marketing Communications, 17(1), 37-49

10. Gunawan, D. D., \& Huarng, K.-H. (2015). Viral effects of social network and media on consumers' purchase intention. Journal of Business Research, 68(11), 2237-2241

11. Habibi, M. R., Laroche, M., \& Richard, M.-O. (2014). The roles of brand community and community engagement in building brand trust on social media. Computers in Human Behavior, 37 ,

12. Hovland, C. I., Janis, I. K. \& Kelley, H. H. (1953). Communication and Persuasion: Psychological studies of opinion change. New Haven, CT, US: Yale University Press

13. Hovland, C. I., \& Weiss, W. (1951). The Influence of Source Credibility on Communication Effectiveness.

14. 15.Influencer Marketing Survey Results: 2019 Industry Benchmarks. (2019).

15. Infographic: Influencer Marketing Outlook 2019 - Report By Bazooka.(2019).

16. Instagram Influencer Rates. (2018). Retrieved January 22, 2019

17. Khamis, S., Ang, L., \& Welling, R. (2016).

18. Lee, Y., \& Koo, J. (2015). Athlete Endorsement, Attitudes, and Purchase Intention: The Interaction Effect Between Athlete EndorserProduct Congruence and Endorser Credibility.

19. Mackenzie, S. B., Lutz, R. J., \& Belch, G. E. (1986). The Role of Attitude toward the Ad as a Mediator of Advertising Effectiveness: A Test of Competing Explanations. Journal of Marketing Research, 23(2), 130-143. doi: 10.1177/002224378602300205

20. Mahapatra, S., \& Mishra, A. (2017). Acceptance and forwarding of electronic word of mouth. Marketing Intelligence \& Planning, 35(5), 594-610. doi: 10.1108/mip-01-2017-0007

21. Mccroskey, J. C. (1966). Scales for the measurement of ethos. Speech Monographs, 33(1), 65-72. doi: 10.1080/03637756609375482

22. McGuire, William J. (1985), Attitudes and attitude change. In Lindzey, G. and Aronson, E. (eds.), Handbook of Social Psychology, 2, 233-346. New York: Random House.

23. Messiaen, J., Hoornaet, S., \& Van den Poel, D. (2017). INFLUENCER MARKETING: HOW the popularity threshold of Instagram influencers impacts consumer behaviour: THE moderating rate of purchase involvement. theses, Ghent University. Retrieved November 2019, from http://lib.ugent.be/catalog/rug01:002351097

24. Mitchell, A. A., \& Olson, J. C. (J. C. (2000). Are Product Attribute Beliefs the Only Mediator of Advertising Effects on Brand Attitude? Advertising \&Amp; Society Review, 1(1). doi: 10.1353/asr.2000.0010

25. Munnukka, J., Uusitalo, O., \& Toivonen, H. (2016). Credibility of a peer endorser and advertising effectiveness. Journal of Consumer Marketing, 33(3), 182-192. doi: 10.1108/jcm-11-2014-1221

26. Neal, Morgan. (2017). Instagram Influencers: The Effects of Sponsorship on Follower Engagement With Fitness Instagram
Celebrities. Theses, Rochester Institute of Technology. Retrieved November16, 2019, from http://scholarworks.rit.edu/theses

27. Neil, A. (2018, April 10). Micro, Macro, And Mega Influencers: Understanding The Difference. Retrieved December 29, 2018 from https://www.liftlikes.com/micro-macro-mega-influencersunderstanding-difference

28. Ohanian, R. (1990). Construction and validation of a scale to measure celebrity endorsers' perceived expertise, trustworthiness, and attractiveness. Journal of advertising, 19(3), 39- 52

29. 31. O'Mahony, S., \& Meenaghan, T. (1997). The impact of celebrity endorsements on consumers. Irish Marketing Review, 10(2), $15-24$

30. Rebelo, M. (2017). How influencers' credibility on Instagram is perceived by consumers and its impact on purchase intention. Dissertation, Catholic University of Portugal. RetrievedaccessedMarch $\quad 17, \quad 2019 \quad$ from http://repositorio.ucp.pt/bitstream/10400.14/23360/1/TESE_FINAL\% 20PDFA.pdf

31. Revell, D. (2017). The Difference Between Micro, Macro and Mega Influencers. Retrieved September 28, 2018 from http://weareanthology.com/we-are-anthology-digital-influencer-andsocial-media-marketing-blog/2017/4/26/the-difference-betweenmicro-macro-and-celebrity-influencers

32. Research Shows Micro-influencers Have More- Experticity. (2016) Retrieved September 28, 2018, from http://go2.experticity.com/rs/288-AZS-731/images/ExperticityKellerFaySurveySummary_.pdf

33. Sammis, K. (2017, April 3). Go Small or Go Home: Despite Criticism, Microinfluencers Are Crushing It. Retrieved from https://adage.com/article/digitalnext/small-home-micro-influencerscrushing/308507

34. Schapers, R. (2018). The rise of influencer marketing-A quantitative study that addresses influencer marketing on Instagram together with the impact of sponsorship disclosure, colour characteristics, brand involvement and gender. Theses. Amsterdam Business School. Retrieved from http://leerstoelcontentmarketing.nl/wp content/uploads/2013/11/thesisrutgerschapers_10202412_thesis_final.pdf

35. Sertoglu, A. E., Catli, O and Korkmaz, S. (2014). Examining the effect of endorser credibility on the consumers` buying intentions: an empirical study in Turkey. International Review of Management and Marketing , 4 (1), 66-77

36. Taghipoorreyneh, M., \& Run, E. C. (2016). Online Advertising: An Investigation of Factors Affecting Positive Attitude among the Malays in Malaysia. Asian Journal of Business Research, 6(2). doi:10.14707/ajbr.160027

37. 39. THE DIFFERENCE BETWEEN MICRO, MACRO AND MEGA INFLUENCERS. (2016). Retrieved March 15, 2019, from http://www.influicity.com/wpcontent/uploads/2018/03/MegaMacroMicro-Whitepaper-min.pdf

38. Thirty Seven Instagram Statistics for 2016. (2016). Retrieved November 30, 2018

39. Willemsen, L. M., Neijens, P. C., \& Bronner, F. (2012). The ironic effect of source identification on the perceived credibility of online product reviewers.18(1), 16-31 